\title{
SURVEY
}

\section{A Brave New World: The Left, Social Engineering, and Eugenics in Twentieth-Century Europe*}

\author{
LEO LUCASSEN \\ Institute for History, Faculty of Humanities, \\ Universiteit Leiden \\ E-mail: 1.a.c.j.lucassen@hum.leidenuniv.nl
}

SUMmARY: This article compares theories and social policies of social democrats and other representatives of the left-wing political spectrum in six European countries to explain why, in certain countries such as Sweden, Norway, and Switzerland, weak social groups became the target of illiberal and negative eugenic policy, especially isolation and sterilization, while elsewhere left-wing politicians and theorists were far less radical. One striking feature that emerges is the difference between a communitarian-organic and a class-bound form of socialism. Following Zygmunt Bauman, Michel Foucault, and James C. Scott, the article discerns a first variant of citizenship that is conditional and intended only for those with the right social attitude. Eugenics was perfectly consistent with such a view, since it offered a diagnosis and at the same time a cure. Prominent representatives of this approach were the Webbs in Britain and the Myrdals in Sweden. Such an organic-medical approach was less likely, however, in a more class-dependent variant of socialism embedded in a strong civil society. As long as social democrats and other leftist politicians believed social problems such as inequality and poverty were caused primarily by an unjust capitalist system, there was little cause for a eugenicist solution.

\footnotetext{
* This article previously appeared in Dutch in a collection of essays edited by Jan van Bavel and Jan Kok, "De levenskracht der bevolking". Sociale en demografische kwesties in de Lage Landen tijdens het interbellum (Leuven, 2010). The translation is by Chris Gordon. I would like to express my appreciation to Jan Kok, Thomas Lindblad, Marcel van der Linden, Jan Lucassen, Anna Petterson, Peter Tammes, and Adriaan van Veldhuizen for their comments on previous versions of this essay.
} 


\section{INTRODUCTION}

In the mid-I970s Sweden's parliament abolished the eugenics-inspired sterilization legislation enacted in 1935 by a social democratic government. During the four decades that passed between implementation and abolition, almost 63,000 Swedes were rendered infertile, in many cases in response to pressure from the state and sometimes as a result of outright compulsion. Furthermore, it was chiefly those regarded as "unproductive" who were the targets of that social policy.

Due especially to the collection of essays published as Eugenics and the Welfare State, which appeared in 1996, we now know a great deal about those eugenicist measures, which were implemented in other Scandinavian counties too. ${ }^{2}$ Those essays build on a slightly older historiography that drew attention to illiberal life-wing policies towards the "underclass", who were regarded as parasitical. That historiography reflected a debate in the I970s and I980s among British historians on the role of left-wing theorists such as the Fabians, ${ }^{3}$ and the importance of eugenics to their theories of social reform. The Fabians (such as Sidney and Beatrice Webb) were especially influenced by the idea that the lowest echelons of society, sometimes termed the "residuum", ${ }^{4}$ had hereditary defects and would increasingly degenerate. In that, they drew inspiration from the work of

I. Gunnar Broberg and Nils Roll-Hansen (eds), Eugenics and the Welfare State: Sterilization Policy in Denmark, Sweden, Norway, and Finland (East Lansing, MI, 1996). See also Alberto Spektorowski and Elisabet Mizrachi, "Eugenics and the Welfare State in Sweden: The Politics of Social Margins and the Idea of a Productive Society", Journal of Contemporary History, 39 (2004), pp. 333-352.

2. A reprint with a new preface appeared in 2005 . For Norway, see also Per Haave, "Sterilization Under the Swastika: The Case of Norway", International Journal of Mental Health, ${ }_{3} 6$ (2007), pp. 45-57.

3. The Fabian Society is a British intellectual movement founded in London in 1884 for the purpose of advancing the principles of social democracy through gradualist rather than revolutionary means. The name Fabian is a reference to the Roman general Quintus Fabius Maximus, nicknamed "Cunctator" (the delayer), because of his tactic of attrition and avoidance (rather than seeking open confrontation) in the war against the Carthagian general Hannibal in the third century before Christ.

4. Around the mid-nineteenth century social reformers used the term "residuum" to refer especially to Londoners who failed to benefit from industrial progress and who were either unemployed or seldom in work. Marx, who used the term "relative surplus population", distinguished between the reserve army of labour and the "unemployable", also termed the lumpenproletariat. See Ann M. Woodall, What Price the Poor? William Booth, Karl Marx and the London Residuum (Aldershot, 2005), p. I. For the term lumpenproletariat see Robert L. Bussard, "The 'Dangerous Class' of Marx and Engels: The Rise of the Idea of the 'Lumpenproletariat', History of European Ideas, 8 (1987), pp. 675-692. See also John Welshman, Underclass: A History of the Excluded I 880-2000 (London, 2006), pp. I-20, and Patricia van den Eeckhout, "'De onbewoonbare krotten zijn etterende middens, waar al de ziekten van het sociaal korps gisten.' De kruistocht tegen de krotwoningen in het interbellum”, in Van Bavel and Kok, "De levenskracht der bevolking". 
the famous statistician, geographer, and anthropologist Sir Francis Galton, a half-cousin of Charles Darwin, thirteen years Galton's senior. It was Galton who coined the term "eugenics", in I883, arguing that the elite should be encouraged to have more children, while procreation among the lower classes should be restricted.'

Thus, the leading Fabian Sidney Webb wrote in The Difficulties of Individualism (1896) about the "breeding of degenerate hordes of a demoralized 'residuum' unfit for social life". 6 That underclass would have many more children than those with superior hereditary material, such as skilled labourers and the middle class. Failure to intervene eugenically, either positively (by encouraging the better citizenry to have more children) or negatively (making it more difficult for the inferior citizenry to procreate), would lead societies to commit race suicide owing to the "rapid multiplication of the unfit", as it was put in the title of a book by the US radical feminist Victoria Woodhull which appeared in I891. ${ }^{7}$ The Webbs argued that it was the duty of the state to take the lead in the matter.

Karl Pearson, a self-professed socialist, ${ }^{8}$ prominent statistician, and, by I9II, head of the Galton Biometric Laboratory and the first Galton Professor of Eugenics, ${ }^{9}$ declared in that respect that

The legislation or measures of police, to be taken against the immoral and antisocial minority, will form the political realization of socialism. Socialists have to inculcate that spirit which would give offenders against the state short shrift and

5. Francis Galton, Inquiries into Human Faculty and its Development (London, I883). The book is a collection of some 40 articles on human heredity which Galton wrote between I 869 and $\mathrm{I} 883$.

6. Sidney Webb, The Difficulties of Individualism (London, I 896). The relationship between the Fabians and eugenicists has been the subject of a recent study by Sören Niemann-Findeisen: Weeding the Garden: Die Eugenik-Rezeption der frühen Fabian Society (Munster, 2004). Unfortunately, I have been unable to locate a copy in any Dutch library. On the internet, only an extensive list of its contents is available.

7. Michael W. Perry, Lady Eugenist: The Rapid Multiplication of the Unfit. Feminist Eugenics in the Speeches and Writings of Victoria Woodhull (Seattle, WA, 2005). On the fear of "race suicide" see also Gareth Stedman Jones, Outcast London: A Study in the Relationship Between Classes in Victorian Society (Oxford, 197I), and Thomas C. Leonard, "Retrospectives: Eugenics and Economics in the Progressive Era", Journal of Economic Perspectives, I9 (2005), pp. 207-224.

8. The extent to which he was a socialist is much disputed by scholars. Influenced by the German philosopher Johann Gottlieb Fichte (I762-I 8 I 4 ), Pearson advocated a strong state and saw little virtue in full democracy. He believed in the fundamental equality of men and women, but his social Darwinist convictions led him to oppose the welfare state, which, he argued, artificially fostered the survival of the "unfit". See Daniel Kevles, In the Name of Eugenics: Genetics and the Uses of Human Heredity (Cambridge, MA, 1985), p. 35. After the I 8900 he continued to be strongly influenced by socialist and Marxist ideas; Theodore M. Porter, Karl Pearson: The Scientific Life in a Statistical Age (Princeton, NJ [etc.], 2004), pp. 104-108.

9. Porter, Karl Pearson, p. 279. 
the nearest lamp-post. Every citizen must learn to say with Louis XIV, l'etat c'est moi. ${ }^{10}$

Some, such as Pearson and Havelock Ellis, a well-known Fabian, took a Social Darwinist approach and categorically rejected any form of support for the "residuum", since such support would inevitably have a "dysgenic" effect. That view is nicely illustrated by Ellis:

The superficially sympathetic man flings a coin to the beggar; the more deeply sympathetic man builds an almshouse for him so that he need no longer beg; but perhaps the most radically sympathetic of all is the man who arranges that the beggar shall not be born. So it is the question of breed, the production of fine individuals, the elevation of the ideal of quality in human production over that of mere quantity, begins to be seen, not merely as a noble idea in itself, but as the only method by which Socialism can be enabled to continue on its present path. ${ }^{11}$

Inspired by Marx, Lasalle, Bebel, as well as Darwin, Pearson was no less radical, advocating what he termed "national efficiency". Socialist nations, he argued, must embrace eugenics, eliminate class antagonisms and inequalities, and promote national unity. Only then could competition from other countries be resisted, "chiefly by way of war with inferior races, and with equal races by the struggle for trade-routes and for the sources of raw materials and of food supply. This is the natural history view of mankind." ${ }^{2}$ So he supported the elimination of Aboriginals in Australia and North America. Sidney Webb did not go so far as to deny the "unfit" all assistance, but he too was unambiguous in his advocacy of negative eugenics. In 1907 he wrote that the superior classes had far too few children and the inferior classes too many. That "adverse selection" was leading to "race suicide", and the country would slowly but surely fall victim to the Irish and the Jews. ${ }^{\mathrm{I}} \mathrm{He}$ proposed a system of state grants for "good" families from the working class, and later argued in favour of segregating the "feeble-minded".

Opinions differ about the significance of eugenics for the left. Many scholars argue that similar biological theories were fairly widespread in Europe and the Americas in the first half of the twentieth century and that they held a great appeal for leftist social reformers. ${ }^{\mathrm{I}}{ }^{4}$ Others claim it was

Io. Diane B. Paul, "Eugenics and the Left", Journal of the History of Ideas, 45 (1984), pp. $567-590,573$.

I I. Havelock Ellis, The Task of Social Hygiene (London, I913), pp. 324-325.

I 2. P. Crook, Darwin's Coat-Tails: Essays on Social Darwinism (New York, 2007), p. I 56. See also Porter, Karl Pearson, p. is I.

I3. Gertrude Himmelfarb, Poverty and Compassion: The Moral Imagination of the Late Victorians (New York, 1991), p. 368.

I4. J.M. Winter, "The Webbs and the Non-White World: A Case of Socialist Racialism", Journal of Contemporary History, 9 (1974), pp. I8 I-192; D. MacKenzie, "Eugenics in Britain", Social Studies of Science, 6 (1976), pp. 499-532; Michael Freeden, "Eugenics and Progressive 
merely an opportunistic flirt, and that such theories did not form a structural element of their philosophy. ${ }^{15}$ There were those too who argued that the Fabians were not real socialists. The current communis opinio is that most Fabians, the Webbs above all, had a major influence on the development of social democracy and on the welfare state in Europe, and that they were strongly influenced by Galton's ideas. ${ }^{16}$

Since the I990s, the debate about the relationship between the "left" and eugenics has become much broader in the wake of Zygmunt Bauman's influential studies of "modernity" and the Holocaust. Bauman describes "modernity" as a process in which to promote greater individual security people are willing to forego a degree of freedom. The managing of risks and uncertainties is left to bureaucracies, which in turn are expected to create order in the chaos of society. Everything which the responsible authorities believe threatens social stability is automatically regarded as a problem. ${ }^{17}$ Closely related to that theory are Foucault's concepts of the "pastoral state", which exercises its power to ensure the health and welfare of its citizens, ${ }^{18}$ and "biopower", with the state endeavouring to control the personal lives of its citizens. ${ }^{19}$ Foucault argues that the state uses a variety of different techniques for the purpose, from statistics and registration to recording personal identities by fingerprinting and photographing individuals.

The emphasis on the role of the state and its use of technocratic methods to discipline the population and so solve social problems is a central theme too in James Scott's Seeing Like a State, which appeared in $1998 .{ }^{20} \mathrm{Scott}$

Thought: A Study in Ideological Affinity”, Historical Journal, 22 (1979), pp. 645-671, and idem, "Eugenics and Ideology", Historical Journal, 26 (1983), pp. 959-962; Paul, "Eugenics and the Left"; Kevles, In the Name of Eugenics; and Mark B. Adams (ed.), The Wellborn Science: Eugenics in Germany, France, Brazil, and Russia (New York, 1990); Crook, Darwin's CoatTails, pp. 249-252.

I s. G.R. Searle, Eugenics and Politics in Britain: 1900-1914 (Leiden, 1976), and idem, "Eugenics and Class", in C. Webster (ed.), Biology, Medicine and Society 1840-1940 (Cambridge, I98I), pp. 2 I 7-242; Greta Jones, "Eugenics and Social Policy between the Wars", Historical Journal, 25 (1982), pp. 717-728. See also D. Porter, "'Enemies of the Race': Biologism, Environmentalism, and Public Health in Edwardian England", Victorian Studies, 34 (I99I), pp. I 59-178, I60.

I6. Daniel Becquemont, "Eugénisme et socialisme en Grande-Bretagne, i 890-1900", Mil neuf cent, I 8 (2000), pp. 53-79, 56.

17. Zygmunt Bauman, Modernity and the Holocaust (Cambridge, 1989), and idem, Modernity and Ambivalence (Ithaca, NY, I99I).

I8. B. Golder, "Foucault and the Genealogy of Pastoral Power", Radical Philosophy Review, io (2007), pp. I57-176.

19. Véronique Mottier, "Eugenics and the Swiss Gender Regime: Women's Bodies and the Struggle against 'Differences'”, Schweizerische Zeitschrift für Soziologie, 32 (2006), pp. 253-268; Gisela Hauss and Béatrice Ziegler, "City Welfare in the Sway of Eugenics: A Swiss Case Study", British Journal of Social Work, 38 (2008), pp. $75 \mathrm{I}-770$.

20. James C. Scott, Seeing like a State: How Certain Schemes to Improve the Human Condition have Failed (New Haven, CT, 1998). 
considers several examples of projects conceived by the state to promote human welfare which turned out to have calamitous effects for those involved, including the forced collectivization of agriculture by the Soviets and the construction of large-scale banlienes in France (inspired by Le Corbusier). According to Scott, many top-down projects of that type prove disastrous because the technocratic planners are seized by a spirit of "high modernism" and fail to take account of local expertise or the needs of the people whose lives the projects are intended to improve.

It is claimed that this "high modernism", which could also be taken to include the social engineering discussed in the present article, was possible above all under dictatorships and in societies with a weak civil society, where, in its planning, the state encountered little if any resistance from citizens or other intervening actors, such as the Church, trade unions, or NGOs. ${ }^{21}$ Independently of Scott, Frank Dikötter came to a similar conclusion in an article on the history of eugenics: "Open democracies with a vibrant civil society, such as Britain and the Netherlands, were generally less inclined to adopt extreme eugenic proposals than authoritarian regimes in Germany and the People's Republic of China."22

Both Bauman and Scott stress that states, particularly authoritarian states, wishing to create a modern well-ordered society were receptive to radical forms of social engineering. With the major role assigned to intervention by state-paid experts, eugenics was easily assimilated into such modernization projects. ${ }^{23}$ Today, there would seem to be a large degree of consensus regarding the relationship between eugenics and the progressive movement, certainly in the first half of the twentieth century, as Paul Crook remarked in his recent book on Social Darwinism: "In fact if you examine the rhetoric of eugenic science [...] you find that it actually best fitted in with contemporary 'progressivist' language that celebrated social engineering and meritocracy, professionalism and the dominance of experts." ${ }^{24}$ According to Weiner, positive eugenics and its

\footnotetext{
2I. Ibid., pp. 4-5.

22. Frank Dikötter, "Race Culture: Recent Perspectives on the History of Eugenics", American Historical Review, I03 (1998), pp. 476-478, 476.

23. Ibid.; Desmond King, In the Name of Liberalism: Illiberal Social Policy in the USA and Britain (Oxford, I999); D. Porter, "Eugenics and the Sterilization Debate in Sweden and Britain Before World War II", Scandinavian Journal of History, 24 (1999), pp. I45-I62; Amir Weiner, "Introduction: Landscaping the Human Garden", in idem (ed.), Landscaping the Human Garden: Twentieth-Century Population Management in a Comparative Framework (Stanford, CA, 2003), pp. I-I 8, 4; Leonard, "Retrospectives: Eugenics and Economics in the Progressive Era”; Natalia Gerodetti, "Eugenic Family Politics and Social Democrats: 'Positive' Eugenics and Marriage Advice Bureaus", Journal of Historical Sociology, i9 (2006), pp. 217-244; and Shelton Stromquist, Reinventing "The People": The Progressive Movement, the Class Problem, and the Origins of Modern Liberalism (Urbana, IL [etc.], 2006).

24. Crook, Darwin's Coat-Tails, p. 25 I.
} 
destructive twin brother "euthanasia" enjoyed virtually universal support during the first half of the twentieth century. ${ }^{25}$ Given the significant opposition to positive eugenics, especially in Catholic countries, that claim is slightly exaggerated, but that many - spanning the entire political spectrum of left to right - were attracted by the ideas of eugenics is indisputable.

In the historiography of the past few decades, by far the majority of studies of left-wing eugenics relate to Britain and the United States. Generally, they lack any comparative perspective, and give relatively little consideration to the role of social democracy. The same cannot be said of a number of more recent comparative studies of Scandinavia, Germany, and Switzerland, ${ }^{26}$ which show that eugenic ideas and programmes found easy acceptance within the ideologies of social democratic welfare states, with their emphasis on a strong state and the subordination of the individual to the community. Although the targets of negative eugenics varied (immigrants, ethnic minorities, or the indigenous underclass), the underlying societal vision shows great similarity.

We should also bear in mind that eugenics did not constitute a welldefined science but was interpreted in widely different ways; and, moreover, that many people involved in the eugenics debate did not necessarily regard the "nature" approach as incompatible with "nurture" factors. ${ }^{27}$ As Dikötter remarked, it was more in the way of being a "modern" approach to discussing social problems in biological terms. And so during the interwar

25. Weiner, "Introduction: Landscaping the Human Garden”, p. 6.

26. Gunnar Broberg and Mattias Tydén, "Eugenics in Sweden: Efficient Care", in Broberg and Roll-Hansen, Eugenics and the Welfare State, pp. 77-I49; Gunnar Broberg and Nils Roll-Hansen, "Preface to the 2005 Edition", in idem (eds), Engenics and the Welfare State: Sterilization Policy in Denmark, Sweden, Norway, and Finland (East Lansing, MI, 2005), pp. ix-xvii; Dikötter, "Race Culture"; Porter, "Eugenics and the Sterilization Debate"; Peter Weingart, "Science and Political Culture: Eugenics in Comparative Perspective", Scandinavian Journal of History, 24 (1999), pp. 163-177; Wiebke Kolbe, Elternschaft im Woblfahrtsstaat. Schweden und die Bundesrepublik im Vergleich 1945-2000 (Frankfurt, 2002); John Rogers and Marie C. Nelson, “'Lapps, Finns, Gypsies, Jews, and Idiots': Modernity and the Use of Statistical Categories in Sweden”, Annales de Démographie Historique, I (2003), pp. 61-79; Alberto Spektorowski, "The Eugenic Temptation in Socialism: Sweden, Germany, and the Soviet Union", Comparative Studies in Society and History, 46 (2004), pp. 84-106; Spektorowski and Mizrachi, "Eugenics and the Welfare State in Sweden"; Véronique Mottier, "Sociaaldemocratie en eugenetica", Socialisme en Democratie, 9 (2003), pp. 20-28, idem, "Eugenics and the Swiss Gender Regime"; idem, "Eugenics, Politics and the State: Social Democracy and the Swiss 'Gardening State", Studies in History and Philosophy of Biological and Biomedical Sciences, 39 (2008), pp. 263-269; V. Mottier and L. von Mandach (eds), Eugenik und Disziplinierung in der Schweiz: Integration und Ausschluss in Psychiatrie, Medizin und Fürsorge (Zurich, 2007); Thomas Etzemüller, "Die Romantik des Reissbretts. Social engineering und demokratische Volksgemeinschaft in Schweden: Das Beispiel Alva und Gunnar Myrdal (1930-1960)", Geschichte und Gesellschaft, 32 (2006), pp. 445-466.

27. Becquemont, "Eugénisme et socialisme en Grande-Bretagne", p. 6r. 
period it became a feature of the political vocabulary of almost every modernizing movement. ${ }^{28}$

The present article therefore goes beyond eugenics policy in a narrow sense; it examines the broader relationship between biologistic ideas and other "left-wing" measures to curtail the rights of individuals under the pretext of protecting society from the "social locus of infection". Though eugenics, with its emphasis on "nature", differs from "nurture-type" policy, such as re-educating the "unsocial", in both cases it was "illiberal" state policy that elevated the interests of what was presumed as the collective above those of the individual.

Having read the historiography, one wonders why eugenics was not embraced by social democrats in all western European countries after World War I. Why did it make such substantial inroads in Scandinavia and Switzerland, and to some extent in Germany, but not in Britain, the Netherlands, nor France? Can such a dichotomy be explained by the former having a weaker civil society and greater scope for "high modernism", as Scott, Bauman, and Dikötter hypothesize? Or was it a reflection more of the nature of social democracy and its relationship to other "players" within the national arena?

In the first case, one could expect all social democratic movements in principle to have embraced some form of illiberal policy in order to improve society. The second hypothesis claims that the form taken by social democratic social policy depended largely on the particular view regarding that welfare state which was to be created and the position of power held by social democrats in relation to other political parties. To answer those questions we shall consider first the Swedish and Swiss cases, before analysing countries in which social democrats declined to embrace eugenics.

\section{THE EUGENIC TEMPTATION IN SWEDEN}

In Sweden, as well as in other Scandinavian countries, ${ }^{29}$ the idea of eugenics as a means to create a better society was influenced strongly by the international debates taking place in Britain, the United States, and Germany..$^{3 \circ}$ In the wake of Galton, Fabians such as the Webbs, George Bernard Shaw, and Havelock Ellis propagated the idea that the welfare state must ensure that the "healthy and fit" should prevail above the "sick,

28. Dikötter, "Race Culture", p. 467.

29. For a useful survey see Broberg and Roll-Hansen, Eugenics and the Welfare State.

30. A good example is Die Rassenhygiene in den Vereinigten Staaten von Nordamerika by Géza von Hoffman, which appeared in I9I 3 and which had a major influence on the Danish social democrat Karl Kristian Steincke; Bent Sigurd Hansen, "Something Rotten in the State of Denmark: Eugenics and the Ascent of the Welfare State", in Broberg and Roll-Hansen, Eugenics and the Welfare State, pp. 9-76, 28. 
parasites and unfit". It was the duty of the state to lead that. Or, as Sidney Webb put it, "No consistent eugenist can be a 'laissez faire' individualist unless he throws up the game in despair. He must interfere, interfere, interfere!" ${ }^{1}$ Like the Fabians, who pioneered Britain's welfare state, ${ }^{32}$ Sweden's social democrats saw little merit in the class struggle. Instead, they regarded the Swedish nation as an organic whole, in which there was no place for spongers and parasites.

Unlike those in Britain, Sweden's socialists were already emphasizing the interests of all the people and not just those of the proletariat as early as the late nineteenth century. In I890, the Swedish socialist Axel Danielsson articulated this communitarian and anti-Marxist socialism, ${ }^{33}$ which expressly included farmers and the lower middle classes. The emphasis on all people was later adopted by the social democrat Ernst Wigforss in his vision of "industrial democracy", a concept that revealed the direct influence of the Fabians. ${ }^{34}$ Closely related to that was the desire of the social democrats to define the boundaries of a Swedish "people's home" (folkhem) $)^{35}$ on the basis of productive rather than ethnic and cultural characteristics. ${ }^{36}$

In Sweden, thinking in terms of "people" rather than class was stimulated further by the interest in the biological and anthropological characteristics of the "Northern race". As early as I 882, the Swedish Society for Anthropology and Geography had conducted a survey of the population in the wake of large-scale emigration to the United States, and in I 909 the Swedish Society for Racial Hygiene was founded, followed in I9I0 by the Mendel Society, the first Swedish genetics association. Even before World War I, leading doctors including Herman Lundborg, a prominent figure in studies of racial biology, saw eugenics as a means to counter the problem of immigration, and there was a widely held opinion that the racial unity of the Swedish people was threatened.

To understand the "Swedish model" properly, with its emphasis on folkhem ${ }^{37}$ as a type of Gemeinschaft, ${ }^{38}$ we must realize that Sweden's

31. Paul, "Eugenics and the Left", p. 570.

32. Spektorowski, "The Eugenic Temptation in Socialism", pp. 86-87.

33. A position adopted by Gunnar Myrdal too; B. Rothstein, "Managing the Welfare State: Lessons from Gustav Möller", Scandinavian Political Studies, 8 (1985), pp. I 5 I-170, I 56.

34. Spektorowski, "The Eugenic Temptation in Socialism”, p. 87; see also T. Tilton, "A Swedish Road to Socialism: Ernst Wigforss and the Ideological Foundations of Swedish Social Democracy", American Political Science Review, 73 (1979), pp. 505-520, 506.

35. A concept introduced in 1928 by the social democrat and later prime minister Per Albin Hansson; Broberg and Roll-Hansen, Eugenics and the Welfare State, p. 5.

36. Spektorowski, "The Eugenic Temptation in Socialism", p. 92.

37. Folkhemmet is also the term for the welfare state as a whole. See also J. Andersson, "Choosing Futures: Alva Myrdal and the Construction of Swedish Futures Studies, 1967-1972”, International Review of Social History, 51 (2006), pp. 277-295, 278.

38. Etzemüller, "Die Romantik des Reissbretts". 
social democrats, who were in government as coalition partners from I917 and who dominated it from 1932, ${ }^{39}$ believed society risked disintegrating because of an all-pervasive anomie. In short, it was the classic problem of "modernity" as formulated by the founders of sociology (Durkheim, Comte, Simmel, and Tönnies). In addition, Swedish socialists pointed to the country's lack of economic development and low rate of population growth, which highlighted the need for an active and interventionist social policy.

From the I920s onwards, the academics and public intellectuals Alva and Gunnar Myrdal (the latter also a Member of Parliament for the Social Democratic Party) played a leading role in shaping and legitimizing that policy. ${ }^{\circ}$ Their role was comparable to that of the Webbs in Britain, except that the Myrdals were supported by the social democrats, who had the added advantage of being in government. In an extremely influential book on the population crisis in Sweden (Kris $i$ befolkningsfragan) which appeared in 1934, they argued that the decline in the rate of population growth should be countered by an active pro-natalist population policy and positive social measures, because otherwise the social integrity of the Swedish people would be endangered. ${ }^{4 \mathrm{I}}$

They regarded the Swedish folkhem as a third way between fascism and liberal democracy, and proposed an unprecedented degree of government intervention. ${ }^{42}$ The faith, both of the Webbs and the Myrdals, in scientific method and analysis and their criticism of ideological prejudice was remarkable. Gunnar Myrdal wanted as far as possible to avoid romanticizing social policy and insisted again and again on the importance of purely rational technical analyses, even if those implied radical solutions. ${ }^{43}$

That position can be seen too in their ideas on, for instance, immigration. Although the Myrdals were not opposed to immigration from neighbouring countries, they regarded immigrants from southern and eastern Europe, Africa, and Asia as a threat to the Swedish people and to Sweden's cultural heritage, ${ }^{44}$ since that sort of immigration would reduce the social standards of the working classes to unacceptable levels. Or, as Gunnar Myrdal cautiously expressed it in 1938, "Immigration to an old country with a well-organized labor market and a rather highly developed

39. Initially with the Farmers' League.

40. Alva Reimer Myrdal was a social psychologist, Gunnar an economist.

4I. Spektorowski, "The Eugenic Temptation in Socialism", p. 93; see Göran Therborn, Between Sex and Power: Family in the World, 1900-2000 (London, 2004), p. 254.

42. Allan Carlson, The Swedish Experiment in Family Politics: The Myrdals and the Interwar Population Crisis (New Brunswick, NJ, 1990), p. xi; Etzemüller, "Die Romantik des Reissbretts".

43. B. Cherrier, "Gunnar Myrdal and the Scientific Way to Social Democracy, I9I4-1968", Journal of the History of Economic Thought, 3 I (2009), pp. 33-55, 40.

44. Carlson, The Swedish Experiment in Family Politics, p. 84. 
structure of social welfare is something which probably does not occur without international friction." 45

It was argued that to prevent Sweden being infected by "foreign elements", the fertility of its indigenous population should be raised, chiefly by making it more attractive for women to have children. Hence their proposal for an extensive system of crèches and paid pregnancy and maternity leave, as well as the right for women to continue in work after marrying. ${ }^{46}$ At the same time, the state must prevent the "wrong" people from procreating. Alva Reimer Myrdal, who was awarded the Nobel Peace Prize in I982, wrote about this in the reissue of an English-language publication Nation and Family which originally appeared in I94 I. "In our day of highly accelerated social reforms the need for sterilization on social grounds gained momentum. Generous social reforms may facilitate home-making and more childbearing than before among the groups of less desirable as well as more desirable parents." 47

It was not the importance of the individual but of the "social body" which was paramount. ${ }^{4}$ The Myrdals hoped that the creation of a wideranging system of state crèches, after-school childcare, and other social amenities would, to some extent, help young children to escape the influence of their parents, and ensure that they could be reared by professionals to become worthy citizens. ${ }^{49}$ By ensuring that children were monitored continually by doctors, teachers, and other professionals, any abnormalities could quickly be detected and remedied. The children reeducated in that way could in turn exercise a healthy influence on their parents, a process which within a few generations would give Sweden better, healthier, and more collectively oriented and harmonious citizens. Unlike national socialists, the Myrdals assumed that participation would be voluntary and would prompt an improvement in the population from

45. Gunnar Myrdal, "Population Problems and Policies", Annals of the American Academy of Political and Social Science, I97 (1938), pp. 200-21 5, 203.

46. See also Silke Neunsinger, Die Arbeit der Franen, die Krise der Männer: Die Erwerbstätigkeit verheirateter Frawen in Deutschland und Schweden 1919-1939 (Uppsala, 2001).

47. Alva Reimer Myrdal, Nation and Family: The Swedish Experiment in Democratic Family and Population Policy (Cambridge, MA, I968), p. 215. Alva Myrdal wrote this book, she claimed, in order to disseminate to an English-language audience the idea of the family-friendly welfare state which she had co-developed with her husband: Nation and Family "is written anew for the public in English-speaking countries. It is, however, at the same time to be considered as a substitute for an British version of the Kris i befolkningsfragan"; Alva Myrdal and Gunnar Myrdal, Kris i befolkningsfragan (Stockholm, I934); Alva Reimer Myrdal, Nation and Family: The Swedish Experiment in Democratic Family and Population Policy (New York [etc.], I94I), p. vii. I am indebted to Jan Kok for drawing my attention to the original 194I edition.

48. Etzemüller, "Die Romantik des Reissbretts", p. 449.

49. Carlson, The Swedish Experiment in Family Politics. 
below, at least as far as "right living" was concerned. ${ }^{50}$ For the socially inferior, coercion rather than voluntariness was envisaged.

Though the Myrdals saw more virtue in positive than in negative eugenics, they were not ill-disposed to the sterilization of those deemed "unfit" and they advocated a fairly radical policy of sterilizing the mentally disabled. ${ }^{\mathrm{I}}$ As technical developments and the demand for efficiency proceeded in industrial society, the question of human quality became urgent. They did not in the first instance regard the "social substratum" as a separate social class, but as a layer of "defectives" recruited from all social classes. And in the case of hereditary defects, society was entitled to intervene, not so much to improve the race, but in the interests of general welfare. In their 1934 book they argued that sterilization of the "deficient" was the inescapable consequence of the great sociological process of adjustment that society was experiencing. ${ }^{52}$

A year after the publication of Kris $i$ befolkningsfraigan the first sterilization law was enacted in Sweden. Sterilization was backed by all the major parties, but it was the social democrat Alfred Petrén (I867-I964), Member of Parliament and Chief Inspector of the Mental Hospitals, who played an especially active role in pushing the law through and implementing it. He regarded sterilization as an alternative to lifelong confinement, which was the fate of the mentally ill and epileptics. He was a strong supporter of social indicators and a vociferous opponent of the principle of voluntarism. He argued that the law should also be applied to "morally inferior individuals", including those unable to care for their children.

In the more stringent legislation of I94I, the concept of "antisociality" was given more central importance: it would actually be more humane to sterilize people who displayed characteristics either hereditary or nonhereditary that made it impossible for them to raise their children property. ${ }^{53}$ Some social democrats actually believed this new law did not go far enough; they were reluctant to be constrained by a hereditary strait-jacket and pushed for sterilization to be applied as well to people whose behaviour was "socially inherited". 54

The I94I law assumed that in general, health care and the welfare state were intended only for those who led respectable lives. One group which did not meet that criterion were the tattare (gypsies/travellers). ${ }^{55}$ In the

50. Etzemüller, "Die Romantik des Reissbretts", p. 454.

5. Broberg and Tydén, "Eugenics in Sweden", p. I04.

52. Ibid., p. I05.

53. See also Maija Runcis, Steriliseringar i folkhemmet (Stockholm, 1998).

54. Spektorowski, "The Eugenic Temptation in Socialism", p. 97.

55. See, for example, in general Leo Lucassen et al., Gypsies and Other Itinerant Groups: A Socio-Historical Approach (London [etc.], 1998). In Sweden, the terms tattare and gypsy were 
period I920-1940 the belief that tattare formed a biological and social threat began to gain wider currency. Of interest in that respect is the anthropometric research conducted by Gunnar Dahlberg in $1944,{ }^{56}$ which revealed no difference between the tattare and the rest of the Swedish population, leading the author to conclude that in this case racial eugenic arguments were fallacious. However, that did not imply that the state should leave the tattare alone. Dahlberg argued that his research showed that social criteria were at least as important, and as a consequence the I94I legislation was deemed applicable to "antisocials" - often without their prior consent - "if they were considered unable to exercise their legal capacity".

With the exception of its democratic character, Swedish communitarian and "productivist" socialism had much in common with fascist and national socialist organic theories on the role of the welfare state. Just as under the Nazis, the welfare state in Sweden had to be protected from "unproductive antisocials" and so it became a "eugenic welfare state of the fittest". 57 The difference with Germany was that in Sweden it was not racial but social criteria that formed the basis for exclusion. That is not to say that there was no criticism of such a radical form of "social engineering”. Criticism was voiced not only in conservative quarters, but also by the far left, including the leftist splinter group of socialists led by Karl Kilbom, who, in the mid-I930s, warned against curtailing the rights of the individual and accused the Myrdals of fascism. It was, though, a voice crying in the wilderness. ${ }^{58}$

Ultimately, in Sweden, between 1934 and 1975 around 63,000 people were sterilized, 90 per cent of them women. Some of that involved voluntary sterilizations, for health reasons or as a form of birth control. However, perhaps one-quarter of those sterilizations were forced on people, largely women, regarded as morally and socially inferior. ${ }^{59}$ During the course of the I950s, the policy gradually became less paternalistic, with the emphasis increasingly on free individual choice. Moreover, the interests of society had given way to those of the individual. ${ }^{60}$

used interchangeably. The tattare were also taken to include sedentary gypsies, but the term was used to refer to vagabonds too, and tramps; Rogers and Nelson, “'Lapps, Finns, Gypsies, Jews, and Idiots'", p. 69.

56. Dahlberg owed his appointment in part to Gunnar Myrdal, and he stayed in close touch with the British left-wing geneticist Lancelot Hogben, whom we shall come across later; Porter, "Eugenics and the Sterilization Debate", p. Is I.

57. Spektorowski, "The Eugenic Temptation in Socialism", p. 85.

58. Carlson, The Swedish Experiment in Family Politics, p. I64.

59. Runcis, Steriliseringar i folkhemmet. See too Broberg and Roll-Hansen, "Preface to the 2005 Edition", pp. ix-xvii.

6o. Ibid., p. xii. 


\section{EUGENICS IN THE SWISS “GARDENING STATE”}

At first sight, the Swiss case differs significantly from the Swedish. Not only is Switzerland a federation, with each canton having a large degree of autonomy, but there was also no social-democratic dominated government, at least not at the federal level. Nonetheless, there too the relationship between the welfare state, social democracy, and social engineering was unmistakeable. ${ }^{6 \mathrm{I}}$

How advanced Switzerland was in the field is best illustrated by the famous Zurich-based psychiatrist and socialist Auguste Forel (I848-I93I). Responding to the spirit of the age, this self-acknowledged eugenicist expressed alarm about the looming degeneration of the Swiss population, and so advocated sterilization legislation and the screening of marriage partners to exclude the "inferior" and thus their issue. Information concerning their hereditary background was therefore necessary. Forel argued that the greatest threat was posed by criminals, prostitutes, and alcoholics, the mentally ill, those suffering from tuberculosis, drug addicts, gypsies, vagrants, Jews, the Chinese, and Negroes; in short every "unordentliche Bürger". ${ }^{62}$ Forel was director of the world-famous Burghölzli Clinic in Zurich and, in 1892 , the first person to perform sterilizations. ${ }^{63}$

Switzerland was also the first country to enact eugenics-inspired legislation, in I9I 2, which made it impossible for the mentally ill to marry. ${ }^{64}$ After World War I the welfare state came to form the institutional framework within which the "inferior" were treated. Since they made for a heavy burden on state finances, partners regarded as socially or morally inferior were permitted to marry only if they agreed to be sterilized. It was on that basis that, in 1928, the canton of Vaud (Waadt) enacted Europe's first eugenics sterilization law; it remained on the statute book until $1985 .{ }^{65}$

Forel, a leading eugenicist, worked closely with psychiatrists and other eugenicists such as Eugen Bleuler and Ernst Rüdin, the latter being also an adviser in Sweden. ${ }^{66}$ Their ideas appealed to the Swiss penchant for "order", which offered no place for deviant social groups such as gypsies and Jews, the mentally ill, the disabled, unmarried mothers, and homosexuals. ${ }^{67}$

\footnotetext{
6I. Gerodetti, "Eugenic Family Politics and Social Democrats".

62. A. Forel, La question sexuelle exposée aux adultes cultivés (Paris, 1906).

63. Jacques Gasser and Geneviève Heller, "Etude de cas: les débuts de la stérilisation légale des malades mentaux dans le canton de Vaud", Gesnerus, 54 (1997), pp. 242-250, 244; Mottier, "Sociaal-democratie en eugenetica".

64. Gerodetti, "Eugenic Family Politics and Social Democrats".

65. Between I9I9 and I944 around 3,000 sterilizations were performed under that law; Philippe Ehrenström, "Stérilisation opératoire et maladie mentale: Une étude de cas", Gesnerus, 48 (1991), pp. 503-516, 503.

66. Broberg and Tydén, "Eugenics in Sweden", p. 92.

67. Mottier, "Eugenics, Politics and the State", p. 265.
} 
There was also the cost factor. Poor relief was a local responsibility, and we see Protestant and social-democratic governed cantons, such as Vaud, Berne, and Zurich, being especially receptive to eugenic arguments and eugenics-inspired measures. ${ }^{68}$ In Zurich in the I930s, for instance, thousands of sterilizations were carried out, almost all of them, as in Sweden, on women from the lower social classes. Closely related to the policy of sterilization was the removal from their parents of some 600 "Jenische" children between 1926 and $1972 .{ }^{69}$ Those children were placed with foster families or put in children's homes; some ended up in psychiatric hospitals or even prison. ${ }^{70}$ Their parents were left in ignorance of their children's whereabouts.

Implementation of that policy was entrusted to a private organization set up in 1926, Hilfswerk für die Kinder der Landstrasse, part of the Swiss Pro Juventute foundation established in I9I 2, which revitalized the policy of assimilation of itinerant groups which had been in effect since i 850 , two years after formation of the federal state, and made them a target of a policy of "normalization".$^{7 \mathrm{I}}$ The motive underlying the policy was articulated eloquently by the founder and, until 1960, director of Hilfswerk, Alfred Siegfried (1890-1972). Although, inspired by the leading psychiatrists of the time such as Robert Ritter ${ }^{72}$ and Josef Jörger, ${ }^{73}$ he believed that the "Jenischen" had a congenital psycho-pathological "Wandertrieb". As a Catholic he was opposed to sterilization; he preferred to isolate and re-educate "Jenischen" children, as is apparent from the following remark made in 1943: "Wer die Vagantität erfolgreich bekämpfen will, muss versuchen, den Verband des fahrenden Volkes zu sprengen, er muss, so hart das klingen mag, die Familiengemeinschaft auseinander reißen. Einen anderen Weg gibt es nicht". [If one wants to fight vagrancy successfully, one must try to destroy the cohesion of the

68. Geneviève Heller and Gilles Jeanmonod, "Eugénisme et contexte socio-politique. L'exemple de l'adoption d'une loi sur la stérilisation des handicapés et maldes mentaux dans le canton de Vaud en 1928", Schweizerische Zeitschrift für Geschichte, 50 (2000), pp. 20-44.

69. Thomas Meier, "Zigeunerpolitik und Zigeunerdiskurs in der Schweiz I850-1970", in Michael Zimmermann (ed.), Zwischen Erziehung und Vernichtung. Zigeunerpolitik und Zigeunerforschung im Europa des 20. Jabrbunderts (Stuttgart, 2007), pp. 226-239, 232 and n. 44. 70. Walter Leimgruber et al., Das Hilfswerk für die Kinder der Landstrasse. Historische Studie aufgrund der Akten der Stiftung Pro Juventute im Schweizerischen Bundesarchiv (Berne, 1998). In principle, the Jenischen were regarded as indigenous, unlike gypsies (later "Sinti and Roma"), who were regarded as foreigners; Meier, "Zigeunerpolitik und Zigeunerdiskurs in der Schweiz I 8 50-1970", pp. 228-229. See also Thomas Huonker and Regula Lufi, Roma, Sinti und Jenische. Schweizerische Zigeunerpolitik zur Zeit des Nationalsozialismus (Zurich, 200I).

71. Meier, "Zigeunerpolitik und Zigeunerdiskurs in der Schweiz i $850-1970$ ".

72. An extensive and in-depth portrait of his life and work can be found in Wim Willems, In Search of the True Gypsy: From Enlightenment to Final Solution (London, 1997).

73. As late as 1964 , Siegfried wrote a book in which he expressly acknowledged his indebtedness to Ritter and Jörger. 
travelling people; although this may sound harsh, one must tear the family community apart. There is no other way. $]^{74}$

It was not until 1972 that the policy was officially terminated, and in the I980s it led to a heated social debate in Switzerland, culminating in a public apology and compensation. ${ }^{75}$ The affair illustrates that "nature" and "nurture" arguments were not mutually exclusive within the realms of social policy, and that in some cases they even reinforced one another. Thus Jörger employed eugenicist arguments to some extent, saying "vagabondage is a form of idiocy and crime" ${ }^{76}$ but he also believed that environmental factors influenced behaviour. Hence, the children were initially placed with Swiss foster families. If good parenting failed to help, one could always opt to prevent them from marrying or to sterilize them ${ }^{77}-$ a practice that strongly resembles the policy pursued in Norway in relation to itinerant groups (tatare). ${ }^{78}$

However, the sterilization policy pursued in several Swiss cantons targeted not so much travelling families as those regarded as antisocial, those who, as in Sweden, formed a danger to the corps social. ${ }^{79}$ The most significant opposition to the policy came from Catholics and liberals, while right-wing and social democratic parties were generally supportive. Thus, in the interwar period, sterilization legislation was adopted by socialist-governed cantons such as Basle, Berne, and Zurich. ${ }^{80}$ The combination of social democracy, the welfare state, and arguments favouring cuts in public expenditure proved especially irresistible for many social democrats. According to Mottier, who has studied at great length the relationship in Switzerland between social democracy and eugenics from a "Bauman-Foucault perspective", one motive underlying the support given by socialists was their ideological affinity with state intervention: "Far from constituting an 'accident' in the history of social democracy, the eugenic social experiments fit in comfortably with core elements of social democratic ideology, in particular the subordination of the individual to the collective interest of the national community." ${ }^{81}$

74. Meier, "Zigeunerpolitik und Zigeunerdiskurs in der Schweiz I850-1970", p. 23 I.

75. Der Schweizerischer Beobachter reported on this policy as early as 1972 , after which it was terminated; the public debate did not really get underway until the i 980 .

76. For a more extensive treatment of these ideas see Willems, In Search of the True Gypsy.

77. Mottier, "Eugenics, Politics and the State".

78. In Norway, children of tatare (in Swedish tattare) were removed from their parents by a state-sanctioned philanthropic religious organization from as early as the beginning of the twentieth century while, under Norway's sterilization law, I 28 tatare were sterilized between I934 and I978; Haave, "Sterilization under the Swastika", pp. 5I-52.

79. Ehrenström, "Stérilisation opératoire et maladie mentale", p. 505; Gilles Jeanmonod, "La mutation du concept de dégénérescence en Suisse romande i870-1920”, Gesnerus, 55 (1998), pp. 70-86, 85 .

80. Hauss and Ziegler, "City Welfare in the Sway of Eugenics".

81. Mottier, "Eugenics, Politics and the State", p. 268. 
Just as in Sweden, what we see here then is a clear case of "high modernism", or in Bauman's words a "gardening state" in which all "weeds" had to be eliminated from the national garden in order to ensure the creation of an exclusive national identity. Although racial differences were emphasized more in Switzerland than in Sweden, in Switzerland too the driving force were communitarian social democrats, who were focused on normalizing society and excluding those regarded as parasites and unproductive. Furthermore, in Switzerland too, "positive" eugenics-inspired measures, such as the institution in the I920s of sex and marriage advice bureaus, were at least as important in social democratic demographic policy. ${ }^{82}$ Socialists especially advocated subsuming personal interests in those of the collective state, as Natalia Gerodetti noted: "Removed from the realm of the private and catapulted into the arena of public concern marital reproduction in particular was a concern of local politicians, many of whom were social democrats." ${ }^{\prime 3}$

\section{A BRIDGE TOO FAR: EUGENICS IN THE BRITISH, GERMAN, FRENCH, BELGIAN, AND DUTCH LABOUR MOVEMENTS}

Although there was no lack of interest in eugenics on the left of the political spectrum in Britain, Germany, France, Belgium, and the Netherlands, unlike in Scandinavia and the Swiss cantons referred to earlier, in none of those countries did that interest lead to sterilization laws nor other forms of negative eugenics. At first sight, that can be explained by a lack of political power and by opposition from other parties: the social democrats were either excluded from participation in government for a long period or had to share power. ${ }^{84}$

Most Catholics were bitterly opposed to intervening in divine providence: with the exception of Britain, the other countries discussed here all had substantial Catholic populations which, at least after 1930, firmly resisted all forms of eugenic interference. In that same year, Pope Pius XI promulgated the encyclical Casti Connubii, which stressed the sanctity of marriage and prohibited all forms of artificial birth control. The encyclical also explicitly spoke out against eugenic laws. ${ }^{85}$ Another factor was

82. Gerodetti, "Eugenic Family Politics and Social Democrats", pp. 227-228.

83. Ibid.

84. The Dutch Social Democratic Workers' Party (SDAP) did not enter government until 1939.

In the UK (1924, I929-193I), Germany (I918-I921, I923, and 1930), and France (I924-I926, 1936-1938) the participation of socialists and social democrats in government was usually brief, and often those governments were coalitions.

85. Ingrid Richter, Katholizismus und Eugenik in der Weimarer Republik und im Dritten Reich. Zwischen Sittklichkeitsreform und Rassenhygiene (Paderborn, 2001). See too Wouter de Raes, "Eugenetika in de Belgische medische wereld tijdens het interbellum", Belgisch Tijdschrift 
the reluctance of most liberal political parties to become involved in eugenic policies.

There are many other indications that the character of civil society in western Europe differed from that in Scandinavia. Unlike Sweden, Norway, and Denmark, other European countries had a less homogenous society, and their greater political, social, cultural, and religious differences led to a much more variegated civil society with a greater likelihood of opposition to ideas which might have far-reaching consequences for the personal domain of certain groups of citizens.

Despite what our initial hypothesis might lead us to assume, the lack of a social-democratic illiberal social policy was not, however, only a question of a lack of political power and the presence of a more resilient civil society. At least as important was the second hypothesis, which accounts for the different experiences in terms of the nature of social democracy and the political and social arena in which it operated. The socialism that was more Marxist-inspired, with the key role it allocated to class antagonisms, seems to have been of crucial importance. Although in most European countries socialists played some part in government, the hatchet of class conflict had not yet been buried and, certainly at the national level, the labour movement represented primarily, rhetorically at least, the interests of the working class. In that context, eugenics, definitely when preached by the middle class, was quickly interpreted as an attempt by the bourgeoisie to stigmatize part of the working class as inferior. That can be seen certainly in Britain and France, but also to a slightly lesser extent in the Netherlands, Belgium, and Germany. It also explains why neo-Lamarckism found much more support in those countries than in Scandinavia and Switzerland. ${ }^{86}$

France (and Belgium) had a particularly strong neo-Lamarckian movement, which, though it acknowledged the role of hereditary influences, also believed in the importance of environmental factors such as poverty and poor housing. The central tenet of neo-Lamarckism was that human characteristics could be hereditary in an unfavourable environment. Moreover, as argued by Van den Eeckhout, ${ }^{87}$ French and Belgian

voor Nieuwste Geschiedenis, 20 (1989), pp. 399-464, 4I6, for the response of Belgian Catholic doctors.

86. Stuart M. Persell, Neo-Lamarckism and the Evolution Controversy in France, 1870-1920 (Lewiston, NY, I999). Jean-Baptiste Pierre Antoine de Monet, Chevalier de Lamarck (I744-1 829) was a French zoologist and botanist. Today he is known principally as the author of the pre-Darwinist evolutionary theory of the inheritance of acquired traits. Following Darwin's publication of the theory of evolution, Lamarck (who had long since died) was rediscovered by neo-Lamarckian scientists, who placed more emphasis on individual will, creativity, and environmental factors.

87. Van den Eeckhout, “'De onbewoonbare krotten””. 
Lamarckian eugenicists were less obsessed by the lower social classes since they did not regard them as irreversibly and biologically inferior. They were more concerned about the three fléaux sociaux (alcoholism, syphilis, and tuberculosis) and, reflecting their obsession with underpopulation, they were more likely to emphasize positive eugenics instead. ${ }^{88}$

An interesting feature and a characteristic of the influence of Lamarckism in Belgium was the work of the famous social scientist and socialist Emile Vandervelde, who, in I893, co-authored with the genetics and botany professor Jean Massart a short book, Parasitisme organique et parasitisme social, in which they compared the biological and social parasite, which both lived at the expense of the other without giving anything in return. Unlike social Darwinists, such as Karl Pearson in Britain, they regarded social parasitism not as hereditary, but as a form of imitation. ${ }^{89}$

We can illustrate the fact that the factors reviewed above were given different weights throughout western Europe by means of the following table.

Table I. Factors hindering the success of leftist negative engenics in Europe

\begin{tabular}{lcccc}
\hline & Catholicism & $\begin{array}{c}\text { Class } \\
\text { antagonisms }\end{array}$ & $\begin{array}{c}\text { Neo- } \\
\text { Lamarckism }\end{array}$ & $\begin{array}{c}\text { Variegated and } \\
\text { strong civil society }\end{array}$ \\
\hline Britain & $+/-$ & $\mathrm{X}$ & - & $\mathrm{X}$ \\
France & $\mathrm{X}$ & $\mathrm{X}$ & $\mathrm{X}$ & $+/-$ \\
Belgium & $\mathrm{X}$ & $\mathrm{X}$ & $\mathrm{X}$ & $\mathrm{X}$ \\
Germany & $+/-$ & $+/-$ & $+/-$ & $+/-$ \\
Netherlands & $\mathrm{X}$ & $+/-$ & $\mathrm{X}$ & $\mathrm{X}$ \\
\hline
\end{tabular}

Legend: $\mathrm{X}$ a major role; $+/-$ a more modest role; - no role, or only a limited role.

The effect of those factors within the various national contexts and how they influenced the attitudes to eugenics and social engineering of socialist and communist parties will be discussed in what follows.

\section{Britain}

As explained in the introduction, Britain was an important breeding ground for leftist eugenicist and illiberal interventionist theories. However, that did not mean those ideas were automatically translated into eugenicist measures. Furthermore, many progressive and left-wing theorists were circumspect about forms of negative eugenics, such as sterilization.

88. Raes, "Eugenetika in de Belgische medische wereld tijdens het interbellum", p. 4II. For France see also Fabrice Cahen, "Medicine, Statistics, and the Encounter of Abortion and 'Depopulation' in France (1870-1920)", History of the Family, I 4 (2009), pp. 19-35, who shows that resistance to abortion was closely linked to fears of population decline.

89. Raes, "Eugenetika in de Belgische medische wereld tijdens het interbellum", pp. $44 \mathrm{I}-442$. 
That circumspection was illustrated well by the publication, in I9I I, of The Prevention of Destitution by Sidney and Beatrice Webb, in which they discussed in rather guarded terms the significance of heredity and emphasized the role of an effective welfare state. ${ }^{90}$ Their book examined the problem of the British underclass, which the Webbs estimated comprised around 4 million people. The underclass was completely demoralized, and lived miserable lives in overcrowded British cities where, because of their antisocial behaviour, they constituted a threat to society. The Webbs referred in this connection to "moral malaria", "bestiality", and "apathy". ${ }^{91}$ Fortunately, they continued optimistically, science was now so advanced that something could be done about it. Moreover, it was absolutely necessary to do it, because otherwise Britain would fall behind other nations industrially and militarily. ${ }^{92}$

The Webbs sought the cause both in hereditary and social factors, for many had succumbed to their desperate situation owing to external circumstances (poverty, ill-health, old age) and through no fault of their own. To solve the problem of destitution, a range of measures was deemed necessary, of which "eliminating bad parentage" was one. ${ }^{93}$ The Webbs were categorically opposed, though, to the Social Darwinist option propagated by Karl Pearson and others, because there was no evidence that it would lead to the "best" being selected. Nor did they have much faith in a unilateral eugenicist approach. ${ }^{94}$ They recognized that poor social conditions might lead to hereditary inferior offspring, for example through alcoholism, ${ }^{95}$ but they continued to insist that the solution lay primarily in improving social conditions. Even "perfect stock" could degenerate in a bad environment. ${ }^{96}$

Although not a dominant group, there were also those on the left sympathetic to the more hard-core eugenicist position, and, remarkably, they were not necessarily ostracized nor even marginalized within the leftist movement. One well-known example is the geneticist J.B.S. Haldane, a member of the Communist Party who was appointed professor at University College London in 1933 and four years later accepted a chair there in biometry. Haldane acknowledged the role of environmental factors, but he claimed that even the best environment could not improve

90. Lynn Hollen Lees, The Solidarities of Strangers: The English Poor Laws and the People, 1700-I948 (Cambridge, 1998), pp. 31 8-319.

91. Sidney Webb and Beatrice Webb, The Prevention of Destitution (London, 19r I), p. 2.

92. For this social-imperialist view see Stedman Jones, Outcast London, p. 327, and Himmelfarb, Poverty and Compassion, pp. 365-369.

93. Webb and Webb, Prevention of Destitution, p. 9.

94. Ibid., pp. 47-48.

95. Current research has demonstrated a clear relationship between alcoholic mothers and brain damage in children born of alcoholic mothers.

96. Webb and Webb, Prevention of Destitution, pp. 50-51. 
a "born idiot". He was chairman of the editorial board of the Daily Worker, the newspaper of the British Communist Party, in which capacity he declared, in 1949, that the dogma of human equality was no part of communism and that socially responsible eugenics was therefore fully justified. It was a view he continued to espouse until his death in $1964 .{ }^{97}$

The socialist and leading American academic Hermann Joseph Muller was another famous left-wing eugenicist. His controversial and popular book Out of the Night: A Biologist's View of the Future (1935), distributed in the UK by the Left Book Club, was in effect a manifesto for eugenicist intervention.

It is easy to show that in the course of a paltry century or two (paltry, considering the advance in question) it would be possible for the majority of the population to become of the innate quality of such men as Lenin, Newton, Leonardo, Pasteur, Beethoven, Omar Khayyam, Pushkin, Sun Yat-sen, Marx (I purposely mention men of different fields and races), or even to possess their varied faculties combined..$^{9}$

Muller, who went on to win the Nobel Prize for Medicine in 1946, worked as a zoologist at the University of Texas until 1932, and spent the next eight years in Europe and Russia. In Out of the Night he argued that, naturally, the environment mattered, but even the best circumstances cannot transform an inherently stupid or selfish person into one who is intelligent or altruistic. ${ }^{99} \mathrm{He}$ also criticized the use of purely economic criteria to determine whether an individual was genetically useful. Given the marked inequality in capitalist societies, it was impossible to separate genetic from environmental factors. A socialist revolution was therefore a prerequisite for ensuring equal opportunities for all. The state would then have to legalize birth control, as well as provide adequate childcare facilities so that mothers could work outside the home (in that, his position was similar to the one espoused by the Myrdals in their I934 book). That would make it possible to prevent families having far too many children and those children then growing up in poverty. ${ }^{\text {Io }}$

If everyone were equal and able to decide for themselves how many children they wanted to have, then the technical eugenic options were unlimited, and included, he argued, the transplantation of fertilized female egg-cells of high quality among women whose hereditary qualities were greatly inferior. Conversely, using artificial insemination, the best men

97. Paul, "Eugenics and the Left".

98. Muller, cited in Elof Axel Carlson, The Unfit: A History of a Bad Idea (Cold Spring Harbor, NY, 200I), p. 350.

99. Diane B. Paul, The Politics of Heredity: Essays on Eugenics, Biomedicine, and the NatureNurture Debate (Albany, NY, I998), pp. 17-18.

Iо0. Carlson, The Unfit, pp. 347-348. 
could reproduce. ${ }^{\text {IOI }}$ In the I930s Lancelot Hogben, who held a chair in social biology at the Fabian-inspired London School of Economics, developed a left-wing version of eugenics. ${ }^{102}$ However, alongside the role of environmental factors he also stressed, like the Webbs in their I9II book on destitution, the inherent class prejudices of many eugenicists. ${ }^{103}$

Socialist and communist scientists such as Haldane, Hogben, and Muller were allowed to defend their views fervently, but ultimately they failed to mobilize many allies in Britain. The ideal state had not yet dawned, and, unlike most Fabians, until it did they continued to regard negative eugenics as a socially biased project of the bourgeoisie whose sole target was the working class. ${ }^{104}$ Like the broader labour movement, they thought primarily in terms of class antagonisms, and in Britain at least that was a key obstacle to the development of the communitarian and collectivist vision of society which we saw in Sweden. ${ }^{\text {IOS }}$ It was an obstacle reinforced by the strong liberal character of the British welfare state which, despite the expansion of pension and insurance arrangements in the I930s, continued to be relatively rudimentary and leaned heavily on individual initiatives, with charitable giving playing an important role. ${ }^{\mathrm{IO}}$

It is hardly surprising then that the campaign undertaken in the I920s by the Eugenics Society for legislation permitting voluntary sterilization came to nothing. The parliamentary bill failed, due not only to controversies between academics, but also, and especially, to strong opposition within the Labour Party; among liberals, aversion to such legislation was almost as great. ${ }^{107}$

\section{Germany}

Opinion on the role of eugenicists in the Social Democratic Party of Germany (SPD) is divided. According to Weindling, hereditary theories

ıо . Paul, The Politics of Heredity, p. I9.

102. Hogben in 1931: "Negative eugenics is simply the adoption of a national minimum of parenthood, an extension of the principle of national minima familiarized in the writings of Sidney and Beatrice Webb. It is thus essentially en rapport with the social theory of the collectivist movement"; Paul, "Eugenics and the Left", p. 574. See also Elazar Barkan, The Retreat of Scientific Racism: Changing Concepts of Race in Britain and the United States Between the World Wars (New York, 1992), pp. 232-233.

I03. Dikötter, "Race Culture", p. 476.

I04. John Macnicol, "Eugenics and the Campaign for Voluntary Sterilization in Britain Between the Wars", Social History of Medicine, 2 (1989), pp. I47-169, and idem, "The Voluntary Sterilization Campaign in Britain, 1918-39", Journal of the History of Sexuality, 2 (I992), pp. 422-438. See also Randall Hansen and Desmond S. King, "Eugenic Ideas, Political Interests, and Policy Variance: Immigration and Sterilization Policy in Britain and the US", World Politics, 53 (2001), pp. 237-263.

I05. As argued too by Porter, "Eugenics and the Sterilization Debate", p. I58.

106. Lees, The Solidarities of Strangers, p. 343.

I07. Macnicol, "Eugenics and the Campaign for Voluntary Sterilization". 
were a marginal phenomenon within the SPD. ${ }^{108}$ More recently, however, historians have pointed out that well before Hitler's rise to power in 1933 German social democrats (including Kautsky, Noske, Valentin Müller, and Grotjahn) and sympathizers (such as the famous sexologist Magnus Hirschfeld) were in fact susceptible to ideas about social engineering and eugenics. ${ }^{109}$ Moreover, especially in the 1920s, many articles were published in SPD circles reporting enthusiastically on the new eugenic possibilities and how they might benefit left-wing social policy. As in Switzerland, they included marriage advice, voluntary sterilization, and abortion. The argument that the lumpenproletariat was responsible for pushing up public expenditure also played a major role.

On the left of Germany's political spectrum, eugenic theories were linked inseparably to the social question right from the late nineteenth century. Many, including the influential progressive doctor Wilhelm Schallmayer, ${ }^{\text {IO }}$ feared their country would degenerate, a fear expressed by the Fabians in Britain too, and so advocated a technological-eugenic solution. ${ }^{\text {II }}$ By minimizing the size of the proletariat, the money that would otherwise have been spent on incarcerating them in prisons and other institutions could be used to emancipate decent and productive workers. ${ }^{\text {II } 2}$ However, those forces were too weak to ensure broad support for socialist eugenics. Nonetheless, as in Switzerland, that support was much greater than in Britain.

A good example was the role of the SPD in Prussia, which, around I930, forged plans together with the Catholic Centre Party (Zentrum) to draft a sterilization law. Despite opposition among Catholics to eugenicist intervention (both positive and negative), participation in government encouraged many Zentrum politicians to consider carefully the problem

108. Paul Weindling, Health, Race and German Politics Between National Unification and Nazism, I870-1945 (New York, 1989).

I09. Mottier, "Sociaal-democratie en eugenetica"; A. Seeck, "Aufklärung oder Rückfall? Das Projekt der Etablierung einer 'Sexualwissenschaft' und deren Konzeption als Teil der Biologie”, in idem (ed.), Durch Wissenschaft zur Gerechtigkeit? Textsammlung zur kritischen Rezeption des Schaffens von Magnus Hirschfeld (Munster, 2003), pp. 173-206, I80; Jürgen Reyer, Eugenik und Pädagogik. Erziehungswissenschaft in einer engenisierten Gesellschaft (Weinheim [etc.], 2003), p. 90.

I 10. Reyer, Eugenik und Pädagogik, p. 56; Sheila Faith Weiss, Race Hygiene and National Efficiency: The Eugenics of Wilhelm Schallmayer (Berkeley, CA, 1987). Schallmayer, who also corresponded with Forel, was a typical representative of the Bildungsbürgertum. He never actually joined the SPD, but he did feel allied to the party, as well as to the genetic meritocratic ideals of Pearson; Weiss, Race Hygiene and National Efficiency, pp. 86 and 174.

I I r. Sheila Faith Weiss, "The Race Hygiene Movement in Germany, 1904-1945", in Adams, The Wellborn Science, pp. 8-68.

I I. Michael Schwartz, Sozialistische Eugenik: Eugenische Sozialtechnologien in Debatten und Politik der deutschen Sozialdemokratie, I890-1933 (Bonn, I995). See also Mottier, "Sociaaldemocratie en eugenetica". 
of the "inferior". ${ }^{13}$ A recent study has shown that among German Catholics eugenicist thinking was much more widespread than assumed until recently, especially among socially left-leaning Catholics, who in Prussia worked closely with the SPD. ${ }^{I 4}$ Inspired by technocratic theories of modernity and the necessity to rationalize society, after a brief incubation period during the I920s, those Catholics embraced part of eugenic philosophy, including its negative variant - sterilization. Particularly the younger generation of Catholic politicians welcomed the new project of the welfare state enthusiastically, and they proved particularly willing to support the negative eugenicist proposals of the Prussian SPD. ${ }^{\text {II }}$

Slowly but surely, Prussia's Zentrum Party, which remained opposed to voluntary abortion, proved amenable to a policy of sterilization, certainly when the costs of the welfare state began to rise alarmingly with the onset of the global economic crisis. It was only with the rise to power of the National Socialists in 1933 that the Catholic and socialist parties recoiled. Ironically, however, that Prussian draft sterilization law, which was ultimately submitted by the Zentrum Party on its own in 1932, formed the basis of the far more radical sterilization legislation of the Nazis. ${ }^{\text {II }}$

\section{France}

France, which like other European countries was seized by fears of degeneracy, had had a strong neo-Lamarckian tradition since the nineteenth century, and the emphasis in that tradition lay on environmental factors and positive eugenics. Interest in positive eugenics was closely linked to concerns about the low birth rate and led to the creation of a pro-natalist movement, supported by the Church and the conservatives, ${ }^{117}$ which in turn accounts for the wide range of measures to protect mothers and children (sometimes termed natalism or puericulture). In addition, there was some acceptance of large-scale immigration from countries such as Italy, Belgium, and Poland. ${ }^{\text {II } 8}$

The global depression of the I930s increased the currency of negative measures such as limits to immigration, restrictions on marriage, and

I 13. Richter, Katholizismus und Eugenik, p. 349.

I 4. Ibid., p. 524. See also Thomas Knapp, "The Catholic Labor Movement in Germany 1850-1933: A Survey and a Commentary", Newsletter, European Labor and Working Class History, 6 (1974), pp. I4-19.

I I 5. Richter, Katholizismus und Eugenik, p. 88.

I 16. Ibid., p. 3 I I.

I17. William H. Schneider, "The Eugenics Movement in France, I890-1940", in Adams, The Wellborn Science, pp. 69-109, 7I and 103.

I 18. Leo Lucassen, The Immigrant Threat: The Integration of Old and New Migrants in Western Europe since I 850 (Urbana, IL [etc.], 2005), p. 92; Clifford Rosenberg, Policing Paris: The Origins of Modern Immigration Control Between the Wars (Ithaca, NY, [etc.], 2006). 
sterilization, as well as triggering a debate on the quality of the considerable immigration of unassimilable races. ${ }^{119}$ However, the conviction that in essence "biology" was determined by poverty rather than the other way round remained entrenched. With the social situation rapidly deteriorating (increasing unemployment and poverty), the French were more easily persuaded to accept eugenic ideas. ${ }^{\text {I2O }}$

In principle, French socialists and communists were not unsympathetic to eugenics, but they preferred the positive variant. In 1935 the communists adopted virtually the entire programme of the French Eugenics Society, because they wanted to prevent the working class degenerating through alcoholism and syphilis. Hence the Communist Party incorporated abortion and "pre-natal screening" into its programme, a policy aim which - ironically enough - would be implemented a few years later under the authoritarian right-wing Vichy regime. ${ }^{\text {I2I }}$ As a result, the communists placed themselves firmly in the communitarian tradition in which the welfare of the entire people was paramount.

In 1935, the chief editor of the Communist Party newspaper L'Humanité, Paul Vaillant-Couturier, became a great advocate of combating alcoholism, slums, prostitution, and social diseases, arguing that otherwise the French people would go under. One solution was birth control, with motherhood being regarded largely as a social function. ${ }^{\text {I22 }}$ Negative eugenics remained in the background, but it did not mean the individual was not required to yield to some extent to society as a whole, a point aptly summarized by William Schneider: "The left certainly had no qualms about government intervention in the private sphere; more important, the family policy could take advantage of the broad appeal of natalist, social hygiene, and eugenic ideas that had been developing in the first three decades of the twentieth century." 23

The aversion to biological determinism in France explains why the most famous French socialist eugenicist, Georges Vacher de Lapouge (I $854-1936$ ), had so little success in his own country. Like Pearson in Britain, Vacher de Lapouge, to whom the origins of "anthroposociology" can be traced, ${ }^{\mathrm{I} 24}$ was a radical disciple of Galton. He believed in hereditary factors only, and also in the existence of races, such as the Aryan,

I 19. As argued by Georges Mauco, Les étrangers en France. Leur rôle dans l'activité économique (Paris, I932), p. 523. See also William H. Schneider, Quality and Quantity: The Quest for Biological Regeneration in Twentieth-Century France (Cambridge, 1990).

I20. Schneider, Quality and Quantity, pp. 75-85.

I 2 I. Idem, "The Eugenics Movement in France", p. Io2.

I22. Ibid., p. 99.

I23. Ibid., p. IO2.

I 24. Jennifer Michael Hecht, "Vacher de Lapouge and the Rise of Nazi Science", Journal of the History of Ideas, 6I (2000), pp. 285-304, 287. 
which far transcended the nation-state. He was convinced that people were fundamentally unequal, and only by rigorously selecting the very best, preferably by artificial insemination, could mankind face the future with confidence and optimism. With ideas of that sort, he became popular in Britain, the United States, and Germany, but not in France itself, where the traditions of the French Revolution and Lamarck dominated. From I902, criticism of his biological determinism swelled to such an extent that his work found an audience almost only abroad. ${ }^{\mathrm{I} 5}$

\section{The Netherlands}

In the Netherlands too, the social question was prominent on the political and social agenda in the second half of the nineteenth century. Around the mid-nineteenth century the Leiden university librarian and classicist Jacobus Geel characterized his less fortunate fellow Leiden citizens as: "the cursed common cattle married before their eighteenth, eat potatoes, have consumptive children, depend on the poor box and beg". ${ }^{26}$ Whereas in Britain and France especially, distrust on the part of the labour movement based on class antagonism acted as an obstacle to the acceptance of eugenics, in the Netherlands Catholicism played an important role, ${ }^{\mathrm{I} 27}$ as did the country's highly diverse civil society and neo-Lamarckian tradition.

Although in subsequent decades many commentators continued to be concerned about the social question, the rapid pace of urbanization, alcoholism, and degeneration, whether or not due to "poisonous germ plasm", ${ }^{\mathrm{I} 28}$ the Lamarckian emphasis on environmental factors remained dominant in the Dutch debate, even among socialists. ${ }^{\text {I29 }}$ That emphasis was reflected in the more nurture-oriented "hygienist" movement, which aimed to address social problems through preventive measures such as better housing, improved water supplies, the construction of sewers, and by combating diseases such as tuberculosis.

I 25. Pierre-André Taguieff, "Sélectionnisme et socialisme dans une perspective aryaniste: Théories, visions et prévisions de Georges Vacher de Lapouge (1854-1936)", Mil neuf cent, I 8 (2000), pp. 7-5I, 23 and $3 \mathrm{I}$.

I26. Jan Noordman, Om de kwaliteit van het nageslacht. Eugenetica in Nederland 1900-1950 (Nijmegen, 1989), p. 37.

I 27. Idem, "Eugenetica en gezinsgrootte, katholieke opvattingen over de bevolkingskwaliteit gedurende het interbellum", Pedagogische verhandelingen, 8 (1985), pp. 318-326.

I 28. Genetic material transmitted by procreation. It was believed that if, for example, during conception one of the partners was inebriated, that might result in "the germ plasm being poisoned". According to the German zoologist August Weismann (I834-I9I4), this inferior genetic material would inevitably multiply by division; Reyer, Eugenik und Pädagogik, p. 63. See also A.F. Petterson, "Kiemvergif en drankbestrijding. De eugenetica van social-democraat G.P. Frets (I879-1957)", paper for the M.Phil. in history, Leiden University, November 2009. I29. Noordman, Om de kwaliteit van het nageslacht, p. 32. 
At the end of the nineteenth century, eugenic determinism was certainly fashionable, as can be seen from the naturalistic novels of Louis Couperus, in which fatalism is a recurrent theme. Nonetheless, many regarded eugenic determinism as excessively materialistic and reductionist. That does not detract from the fact that many observers interpreted social problems in biological terms also, as is evident from the debate on neurasthenia, which was explained as being an exhaustion of the central nervous system attributable to the intense pace of modern civilization. Many doctors believed that this "disease of modern civilization" was partly hereditary. ${ }^{130}$ And so there were enough eugenicists, such as Marie Anne van Herwerden (I874-1934), Reader in Biology at the University of Utrecht, who believed that the social developments taking place were leading to a significant increase in the number of socially inferior individuals, who in turn promoted antisociality. ${ }^{\mathrm{II}}$ Ideas like that could be found repeated in a wide range of journals, including the influential sociological journal Mensch en Maatschappij, and such thinking was far from marginal among doctors and psychiatrists. ${ }^{{ }^{132}}$ Furthermore, that those ideas were more than theoretical can be seen by the castration of some 400 homosexuals between 1938 and I969, though the term eugenics was carefully avoided. ${ }^{\mathrm{I} 33}$

Nonetheless, why it was that so few Dutch social democrats ${ }^{\mathrm{I}} 34$ felt drawn to eugenics can probably be explained by the following factors. To begin with, unlike in Britain or France there was no imperialistic social

I30. Leonie de Goei, De psychohygiënisten: psychiatrie, cultuurkritiek en de beweging voor geestelijke volksgezondheid in Nederland, 1924-1970 (Nijmegen, 2001). See also L. Nys et al. (eds), De zieke natie. Over de medicalisering van de samenleving I860-I9I4 (Groningen, 2002). I3 I. De Goei, De psychohygiënisten, p. 27.

I32. As argued by Noordman, Om de kwaliteit van het nageslacht; De Goei (De psychobygiënisten, p. 48) qualifies that view. See also H. Biervliet et al., "Biologisme, racisme en eugenetiek in de antropologie en de sociologie van de jaren dertig", in F. Bovenkerk et al. (eds), Toen en thans. De sociale wetenschappen in de jaren dertig en $n u$ (Baarn, I978), pp. 208-235, S. Snelders and T. Pieters, "Van degeneratie tot individuele gezondheidsopties. Het maatschappelijk gebruik van erfelijkheidsconcepten in de twintigste eeuw", Gewina, 26 (2003), pp. 203-215, and idem, "Alcoholism and Degeneration in Dutch Medicine around 1900", in Patrick Dassen and Maria Kemperink (eds), The Many Faces of Evolution in Europe,

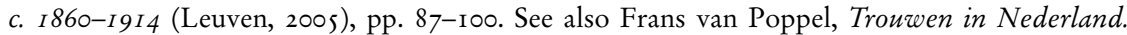
Een historisch-demografische studie van de Ige en vroeg-20e eeuw (Wageningen, 1992), pp. IOI-IO3, who discusses the ideas of H. Treub, S.R. Steinmetz, and C.J. Wijnaendts Francken. I33. Theo van der Meer, "Eugenic and Sexual Folklores and the Castration of Sex Offenders in the Netherlands (1938-1968)", Studies in History and Philosophy of Biological and Biomedical Sciences, 39 (2008), pp. 195-204, 200-201.

I34. The exceptions included SDAP members A.E.J. de Vries-Bruins, F. Wibaut (son of the famous alderman), the doctor and chairman of the Dutch Eugenics Federation G.P. Frets, the criminologist Willem Bonger, F. Koster, the teacher and temperance advocate F.U. Schmidt and, after the war, PvdA member Jannetje Zeelenberg; Noordman, $O m$ de kwaliteit van het nageslacht, pp. I66-I68; Henny Buiting, "Linkse eugenetica in Nederland", Onvoltooid Verleden, 2 (1998); Petterson, "Kiemvergif en drankbestrijding". 
preoccupation with the declining quality of the population, and especially of the quality of recruits to the army. Further, not only was the urban proletariat relatively small, but urbanization was on a smaller scale and developed more gradually than in Scandinavia, Germany, Switzerland, and France for example. The west of the Netherlands already constituted one of the most urbanized regions of the world in the early modern period. Thirdly, as in Britain, during the interwar years the social democrats were involved only peripherally in and responsible for the construction of the welfare state, again unlike what happened in Scandinavia, Switzerland, and Weimar Germany. And, as we have seen especially in the Swedish case, in their ideas about the role and costs of the welfare state socialists were easily tempted to adopt eugenic ideas. Moreover, in the Netherlands the state took a relatively cautious role in the design of a welfare state which was administered from the top but left much to private initiative, both religious and secular. That option was related closely to the denominational nature of organized social life, characterized as it was by the emphasis on "sphere sovereignty", which ensured a resilient and powerful civil society.

Given that after World War I the SDAP did acquire political responsibility at the local level, it is interesting to analyse the social policy they developed. In the four major cities of Amsterdam, Rotterdam, Utrecht, and The Hague, the socialists produced aldermen who were closely involved in the construction of the welfare state and who advocated greater intervention in social life. For the purpose of our argument, the attempts to re-educate "antisocials" and "unsocials" in the interwar period were important in that context, for which many SDAP aldermen and officials tried to derive credit. ${ }^{35}$ During the interwar period, they laid the groundwork for the so-called woonscholen (literally, housing schools), small isolated complexes on the peripheries of cities (Amsterdam, Rotterdam, Utrecht, and The Hague), where slum dwellers were accommodated and taught by social workers how to lead a "decent" life. ${ }^{{ }^{136}}$

Although such projects were not very large in scale, and in principle the people involved were free to leave the complexes, they show that, unlike their Belgian counterparts, ${ }^{\mathrm{I}}{ }^{37}$ Dutch socialists too were not averse to social engineering. Though hardly eugenic in nature, their policy was designed to subdue "unproductive" and "antisocial" citizens, so allowing collective interests to prevail over those of the individual. However,

I35. Well-known examples being Arie Keppler, Director of Amsterdam's Municipal Housing Department, and the psychiatrist A. Querido.

136. Ali de Regt, Arbeidersgezinnen en beschavingsarbeid. Ontwikkelingen in Nederland I870-1940 (Meppel [etc.], I984); Adrianne Dercksen and Loes Verplanke, Geschiedenis van de onmaatschappelijkheidsbestrijding in Nederland I9I4-1970 (Meppel [etc.], I987); Ben Maandag and Tonny van der Mee, De asocialen. Heropvoeding in Drentse kampen (Rotterdam, 2005). I37. See Van den Eeckhout, “De onbewoonbare krotten'”. 
unlike in Sweden and Switzerland it went no further than modest, tentative steps along the path of high modernism.

Finally, another good example illustrating the fact that the majority of Dutch - and British - social democrats lacked the same eugenicist impulse for social engineering as seen in Sweden and Switzerland is their policy towards "gypsies" and other traveller groups, who were prominent targets of policy in both Sweden and Switzerland. Unlike in Germany, Switzerland, Norway, and Sweden, those groups were left more or less alone by British and Dutch central and local government. In Britain and the Netherlands, the authorities did attempt to remove itinerant foreigners across the border, while municipalities refused access to Dutch caravandwelling families where possible. ${ }^{138}$ There were certainly no serious endeavours to civilize them, let along sterilize them - certainly not before World War II. ${ }^{39}$ That lack of interest was consistent with the general idea of the national population being defined less in organic terms ("social body") than it was in Scandinavia and in German-speaking countries.

\section{CONCLUSION}

This article has compared the theories and social policies of social democrats and other representatives of the left-wing political spectrum in six European countries. Its chief focus has been the question of how we can explain why, in certain countries such as Sweden, Norway, and Switzerland, weak social groups were the target of illiberal and negative eugenic policy, especially isolation and sterilization, while in other countries left-wing politicians and theorists were far less radical (positive eugenicists, neo-Lamarckians).

To answer the central question posed here, I tested two hypotheses: the first is derived from the work of Zygmunt Bauman, Michel Foucault, and James Scott and emphasizes the desire of the state and the technocrats and professionals associated with that state to crack down on those elements of the population who found themselves unable to cope with social change and unable to assimilate themselves into modern society, and indeed to eliminate them, by, in the most extreme cases, sterilizing or

138. Annemarie Cottaar, Kooplui, kermisklanten en andere woonwagenbewoners. Groepsvorming en beleid, I870-1945 (Amsterdam, I996); idem et al., "Justice or Injustice? A Survey of Government Policy towards Gypsies and Caravan Dwellers in Western Europe in the Nineteenth and Twentieth Centuries", Immigrants and Minorities, I I (1992), pp. 42-66; Leo Lucassen, "Between Hobbes and Locke: Gypsies and the Limits of the Modernization Paradigm”, Social History, 33 (2008), pp. 423-44I.

I39. Leo Lucassen, "Gypsy Research and Gypsy Policy in the Netherlands (1850-1970) in a Comparative Perspective", in Michael Zimmermann (ed.), Zwischen Erziehung und Vernichtung. Zigeunerpolitik und Zigeunerforschung im Europa des 20. Jabrhunderts (Stuttgart, 2007), pp. 240-253; Willems, In Search of the True Gypsy; David Mayall, Gypsy Identities I 500-2000: From Egipcyans and Moon-Men to the Ethnic Romany (London, 2004). 
killing them (Nazis). In that view, the political convictions of policymakers are subordinated to a shared "high modernist" ideology. The vision of the future offered by the Myrdals, and to a somewhat lesser extent by the Webbs, was wholly consistent with that. They were enthusiastic advocates of a rational and technocratic ideology designed to solve social problems, without taking much account of the expertise and opinion of the population on whom that policy would be inflicted.

Although such a hypothesis is seductive, it would seem - ironically enough - to be the victim of the phenomenon it purports to explain, since the approach of Scott and others pays relatively little attention to opposing forces, inconsequences, or unintended effects. ${ }^{140}$ Moreover, and more importantly for our theme, it fails to explain why in countries such as Britain, France, the Netherlands, and Germany, the "left" was much less eager to follow the example of their counterparts elsewhere.

That brings us to the second hypothesis, the nature of left-wing ideology, which manifested itself primarily in the concept of class antagonism and which permeated the design of the welfare state. When we compare the six countries considered in our study, one striking feature that emerges is the difference between a communitarian-organic and a class-bound form of socialism. The first variant can be found chiefly in Sweden, appropriately captured by the term folkhem(met), which means something like a home (bem) in which all people can feel at ease; it is also the term for "welfare state". At the other extreme is the orientation towards class antagonism, with Britain as its most pronounced representative.

Closely associated with the communitarian-organic variant of the welfare state is the distinction between productive and unproductive citizens. ${ }^{14 \mathrm{I}}$ Where the welfare state is regarded as a single large supportive and unified community, those members who do not observe the rules or simply profit from it soon become a liability, and not only in a financial sense, but morally too. There, citizenship is conditional and intended only for those with the right social attitude. ${ }^{\mathrm{I} 4^{2}}$ By regarding society as a single organism, there is a great temptation to view weak social groups in medical terms of "sickness" and "infection". Moreover, it legitimizes restricting the rights

I 40. On this criticism see also Charles Tilly, "Power - Top Down and Bottom Up", Journal of Political Philosophy, 7 (1999), pp. 330-352, and Frederick Cooper, Colonialism in Question: Theory, Knowledge, History (Berkeley, CA [etc.], 2005).

I4I. For the relationship between communitarianism and illiberal theories, including eugenics, see too Sheri Berman, The Primacy of Politics: Social Democracy and the Making of Europe's Twentieth Century (New York, 2006), p. 207.

I42. The concept of "conditional" can also be seen in the postwar Eastern bloc, where one of the state's objectives was to create the new socialist man; often those were states that stressed the importance of ethnic homogeneity, such as Czechoslovakia; Celia Donert, "'The Struggle for the Soul of the Gypsy': Marginality and Mass Mobilization in Stalinist Czechoslovakia”, Social History, 33 (2008), pp. I23-I44, I 30. 
of the individual on the grounds that doing so serves the interests of the community. Eugenics was perfectly consistent with such a view, since it was both diagnosis and at the same time cure. The Webbs and the Myrdals too were prominent representatives of that approach.

Such an organic-medical approach was less likely in a more classdependent variant of socialism. As long as social democrats and other leftist politicians believed social problems such as inequality and poverty were caused primarily by an unjust capitalist system, there was little cause for a eugenicist solution. Instead, attention was directed towards a moderate form of class struggle and on countering liberal and confessional opposition. Furthermore, class-dependent socialists accused eugenicists of a onesided and prejudiced approach, because they targeted only the socially vulnerable, something many found sincerely objectionable as well as being electorally unwise. The position of the Anglo-Saxon eugenicists Hogben, Muller, and Haldane, most of whom were communists, illustrates this political analysis. Eugenics was fine, but first the classless society had to be realized.

That second hypothesis does not exclude the "high-modernist" approach entirely though. As we have seen, technocratic forms of social engineering played a major role in shaping illiberal policy. Moreover, the nature of civil society, which Dikötter regarded as a potential buffer against "high modernism", was indeed an important factor. Despite what is generally assumed, the resilience and influence of civil society can also vary markedly in democracies which in theory operate well. In states ethnically, politically, and religiously relatively homogenous, such as Sweden and Norway, resistance to radical social policy was fairly limited; ${ }^{143}$ in countries more sharply divided along political and religious lines, such as Britain and the Netherlands (with its characteristic pillarization), no consensus could be reached; in concluding this, we should regard the inhibiting influence of Catholicism as a component of that civil society.

The distinction between the two sorts of socialism does not, though, explain developments after World War II. Influenced by the ideas of Beveridge and Keynes, the postwar period saw the emergence of a universal welfare state, which bore a close relationship to the communitarianorganic vision of the social democrats. Contrary to what one might have expected based on the analysis of the interwar period, that did not lead to a more stringent and illiberal social policy. The explanation is fairly simple. In the postwar welfare state social rights (such as benefits) became largely disconnected from productive obligations. ${ }^{\mathrm{I} 4}$

I43. See also Rogers and Nelson, “'Lapps, Finns, Gypsies, Jews, and Idiots”, p. 75.

I44. T.H. Marshall, Social Policy in the Twentieth Century (London, 1979); Gøsta EspingAndersen, The Three Worlds of Welfare Capitalism (Cambridge, 1990); Andreas Fahrmeir, Citizenship: The Rise and Fall of a Modern Concept (New Haven, CT, 2007). 
Moreover, after 1945 the radicalization of the racial social policies of the Nazis before and during World War II led to a huge mistrust of anything that even remotely smacked of racism or invasion of privacy, even if that did not apply to all groups, as Swiss policy towards the "Jenischen" demonstrated. The gradual turning point in Swedish sterilization practice in the I950s, which saw greater emphasis on voluntarism and the interests of the individual, illustrates this paradigm shift. It was only with the reform of the welfare state and cuts in welfare expenditure in the I980 and later, ${ }^{145}$ and the rise of populism and neo-nationalism, that the illiberal aspects of the communitarian-organic model once again seemed to gain greater acceptance throughout western Europe, a point illustrated by policies towards ethnic minorities and the "underclass", which have increasingly been problematized and categorized as alien and unproductive members of society.

It is a view by no means alien to many social democrats, as is evident from the debate in the Netherlands in response to the Dutch Labour Party resolution on integration in the early months of $2009 .{ }^{146}$ In that resolution, drafted by high-ranking party officials and deeply influenced by the communitarian vision of Paul Scheffer, a very influential party member and public intellectual, ${ }^{\mathrm{I}}{ }^{47}$ integration was to a large extent portrayed as a cultural problem caused by Islam. And, consequently, the solution would be for the Dutch-resident Moroccan and Turkish Muslim populations to adopt Dutch norms and values.

At the same time, social and economic causes, such as unemployment and the low level of human capital of the first generation, were largely downplayed. As the Rotterdam sociologists Schinkel and Van den Berg claim, because of its emphasis on consensus and on projecting Dutch society as a coherent whole, the current debate on integration and citizenship seems actually to promote antagonisms along ethnic lines between those who have lived in the Netherlands for a long time and those who have only recently arrived. In that sense, it is consistent with the communitarian-organic tradition, whose roots have been exposed in the present article. ${ }^{\mathrm{I} 8}$

I45. Saskia Sassen, Territory, Authority, Rights: From Medieval to Global Assemblages (Princeton, NJ [etc.], 2006).

I46. Socialisme en Democratie (January/February 2009) and Rood. Het ledenblad van de Partij van de Arbeid, 2 (2009). See also Leo Lucassen and Wim Willems, "De ondraaglijke lichtheid van het geheugen", Rood. Het ledenblad van de Partij van de Arbeid, I (2009), p. I9.

147. Paul Scheffer became widely known through his Het land van aankomst (Amsterdam, 2007), which has been reprinted twelve times since it originally appeared.

I48. Willem Schinkel and Margueritte van den Berg, "Polariserend en moraliserend burgerschap in de inburgering", in Raad voor Maatschappelijke Ontwikkeling (ed.), Polarisatie. Bedreigend en verrijkend (Amsterdam, 2009), pp. I88-205. 